Final Report

\title{
Search for Ancient Microorganisms in Lake Baikal
}

J. C. Hunter-Cevera, ${ }^{1}$ V. E. Repin, ${ }^{2}$ and T. Torok ${ }^{3}$

\author{
${ }^{1}$ University of Maryland Biotechnology Institute \\ ${ }^{2}$ State Research Center of Virology and Biotechnology \\ "VECTOR" \\ ${ }^{3}$ Lawrence Berkeley National Laboratory
}




\section{Table of Contents}

1. Executive Summary 3

2. Background and Significance 4

2.1 Microbial Diversity by Definition 4

2.2 Lake Baikal 4

2.3 East-West Scientific Cooperation 5

2,4 Project Objectives 5

2.5 Tasks and Deliverables 5

3. Progress Report 7

3.1 Sample Collection $\quad 7$

3.2 Microbiological Examination 10

3.3 Microbial Diversity Characterization 11

3.4 Discussion and Conclusions 14

4. Publications and Presentations 16

5. Acknowledgement 18

6. References 18

$\begin{array}{ll}\text { Appendix A } & 21\end{array}$

$\begin{array}{ll}\text { Appendix B } & 79\end{array}$

$\begin{array}{ll}\text { Appendix C } & 92\end{array}$ 


\section{Executive Summary}

Lake Baikal in Russia, the oldest and deepest continental lake in the world lies in south central Siberia. The Lake represents a unique niche in nature based on its historical formation. The microbial diversity in this environment has not yet been fully harvested or examined for products and processes of commercial interest and value. This Thrust I project enabled us to collect water, soil, and sub-bottom sediment samples, and characterize the microbial diversity present. The intensive isolation program helped increase the number of "culturable" microorganisms: over 2,200 strains were isolated and preserved. The isolated microorganisms were identified based on biochemical tests. They were further characterized via whole-cell fatty acid methyl ester (FAME) analysis, genomic DNA fingerprinting, and restriction enzyme profiling. Also, a larger subset of isolates underwent electron microscopic cell morphology and fine structure investigations.

With the project, we undertook the first step in bioprospecting this untapped wealth for exploring the microbial diversity and analyzing the microbial products of high commercial interest and value. Based on the success of the project, under participation of DuPont Agriculture Division, a Thrust II program was awarded just recently.

The following Final Report contains background and significance information and a short progress report. It closes with concluding remarks, a list of publications and presentations of the work at national and international meetings, and acknowledges the support and dedication of many people. The milestone reports, the trip reports, and a table of cumulative spending to date are attached as appendices. 


\section{Background and Significance}

\subsection{Microbial Diversity by Definition}

Microbial diversity includes the genetic composition of microorganisms, their environment or habitat where they are found, and their ecological or functional role within the ecosystem (Hunter-Cevera, 1998). In the past two decades our knowledge of microbial diversity in the area of phylogeny, taxonomy, and microbial ecology has increased dramatically. Discovering the untapped diversity of microorganisms is the resource for new genes and products of value to biotechnology. A quite pristine, and in geological terms "ancient" ecological niche like Lake Baikal was assumed to be very valuable.

\section{$2.2 \quad$ Lake Baikal}

Lake Baikal in Russia, the world's oldest and deepest continental lake lies in south central Siberia, near the border to Mongolia. It covers $31,500 \mathrm{~km}^{2}$ and is $636 \mathrm{~km}$ long and $48-79 \mathrm{~km}$ wide. Its average depth is $730 \mathrm{~m}$. The maximium depth in the middle is $1,620 \mathrm{~m}$. Its shoreline extends to 1,245 miles. The lake's water basin occupies about $557,000 \mathrm{~km}^{2}$. The volume of the fresh water is approximately $23,000 \mathrm{~km}^{3}$, i.e., one-fifth of all the terrestrial fresh water on Earth. Lake Baikal occupies the deepest portion of the Baikal Rift Zone, one of the two major continental rift zones in the world. The rift is over $9 \mathrm{~km}$ in depth. Lake Baikal was formed some 35-40 million years ago.

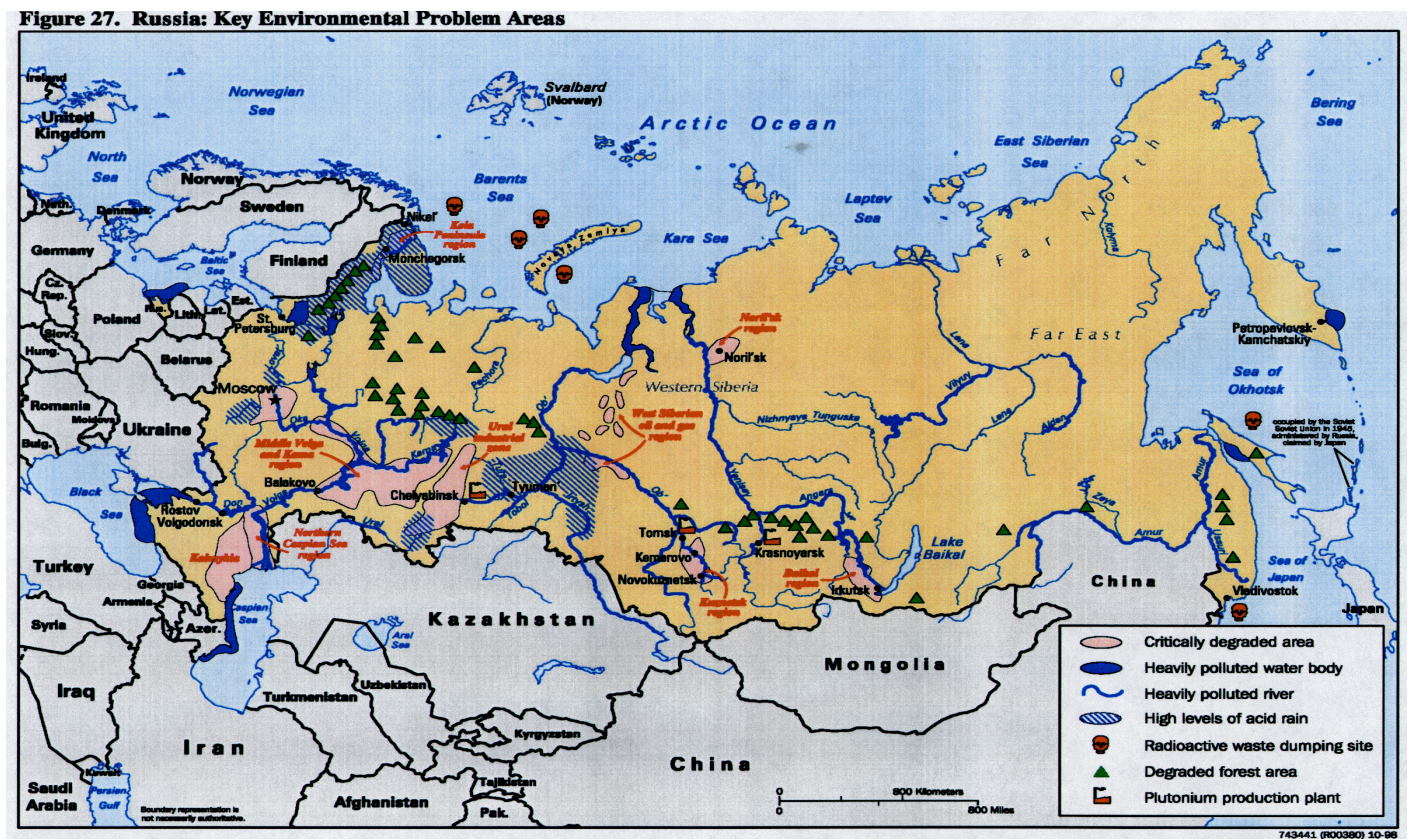

Figure 1 A 1998 map of the Russian Federation. Lake Baikal, except for its southern most tip, represents a pristine environment. 
Lake Baikal is a self-contained aquatic system. It is an isolated ecosystem, home to more than 1,500 unique endemic species. These are three-fourth of plant and animal species living there. There are also several thermal springs near the lake.

\subsection{East-West Scientific Cooperation - Significance of Proliferation Prevention}

The end of the Cold War in the late 1980s made the active development of largescale east-west cooperative scientific projects in Lake Baikal possible. One of them, the Baikal Drilling Project (BDP) has evolved since 1989 into a multinational effort involving Russian, American, Japanese, and German scientists. Multidisciplinary studies since then have helped reconstruct a continuous paleoclimatic record for the last 5 million years (Williams et al., 1997a; 1997b; 1997c).

The Initiatives for Proliferation Prevention (IPP) program of the U.S. Department of Energy is the successful conversion program that targets former Soviet nuclear, chemical, and biological warfare agent R\&D and production facilities and their research teams. The program, while it achieves its political-economical stabilizing objectives and national security goals, has opened new avenues for scientific cooperation between U.S. and NIS researchers. The IPP program has provided the framework for this Thrust I project between Lawrence Berkeley National Laboratory, a DOE national laboratory and VECTOR, the State Research Center of Virology and Biotechnology, one of the largest former "Biopreparate" R\&D and production facilities.

\section{$2.4 \quad$ Project Objectives}

Lake Baikal represents a unique niche in nature based on its location and historical formation. The microbial diversity present in this environment has not yet been fully harvested or examined for products and processes of commercial interest and value. Thus, the collection of water, soil, and sediment samples was decided. It was expected that new isolation techniques and media would help increase the number of "culturable" microorganisms. In addition, the sequencing of genes from those microorganisms that currently cannot be cultured would provide information on possible "new genes", which then can be cloned for expression of novel capabilities.

\section{$2.5 \quad$ Tasks and Deliverables}

To achieve the set goals and objectives of the project, the participants agreed to perform the following tasks.

- Describe and characterize the sampling site(s) at Lake Baikal. The description provided relevant physical, chemical, and geological information necessary to develop sampling plans and draw conclusions in the search for ancient microorganisms. [VECTOR] 
- Describe sampling techniques. Aseptic sampling was needed. Also, the number and types of samples were decided. [LBNL and VECTOR]

- Collect samples in Lake Baikal. [LBNL and VECTOR]

- Process samples for DNA extraction. Immediately after sample collection, 50-ml BluMax tubes were filled with samples and frozen. These tubes were kept at low temperature, preferably at $-86^{\circ} \mathrm{C}$, until shipping to LBNL for DNA extraction and further processing. [LBNL and VECTOR]

- Isolate microorganisms. Participants agreed on isolation techniques and growth media so that the largest possible number of microorganisms could be isolated. LBNL preferred a schedule that LBNL scientists could work with colleagues at VECTOR when the microorganisms were being isolated. [LBNL and VECTOR]

- Process isolated microorganisms for shipment to LBNL. Isolated microorganisms were preserved for long-term maintenance immediately after isolation. Controlled freezing of cultures in glycerol was preferred. [LBNL and VECTOR]

- Screen received isolates for the expression of products of interest to industry and biotechnology. [LBNL and VECTOR]

- Identify isolated microorganisms. Using available means of microbial identification, NIS-scientists attempted a preliminary characterization of the isolated microbial cultures. [VECTOR]

- Further screen isolated cultures for biologically active compounds of interest. [LBNL]

- Process microbial products for shipment to LBNL. Cultures and microbial products, fermentation extracts, etc., of mutual interest were sent to LBNL for further screening. [VECTOR]

- Conclude data processing and consult NIS-scientists to finalize search for ancient bacteria. Based on collected identification and molecular-level characterization data, participants agreed on descriptions for microorganisms so that the search for ancient microorganisms could be completed. [LBNL]

- Participate in a project closing and Thrust II project planning meeting at LBNL. [LBNL and VCTOR]

- Prepare the final report on collaboration. The final report contains detailed notes on the entire project and emphasizes the perspectives for commercializable products. [LBNL and VECTOR] 


\section{Progress Report}

The goal of the project was to investigate the microbial diversity of the isolated strains of aerobe and facultative anaerobe heterotrophs in our samples, especially, focus on the diversity of bacilli, actinomycetes, and fungi due to their primary importance to biotechnology. Isolated microorganisms were characterized via cell morphology and fine structure, conventional biochemical tests, fatty acid methyl ester analysis, genomic fingerprinting, and restriction enzyme profiling.

\subsection{Sample Collection}

In the context of the unique features of Lake Baikal, the following sampling sites were chosen and samples collected.

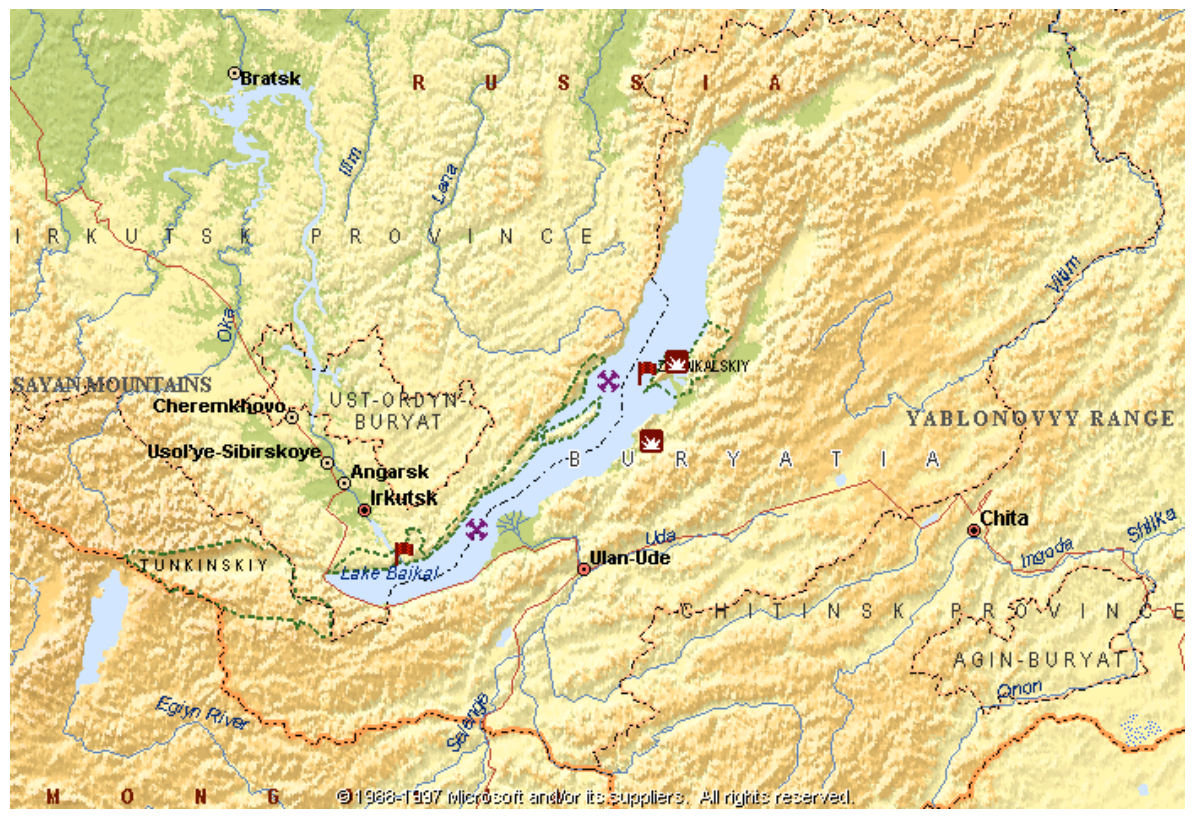

Figure 2 Map of Lake Baikal [Flags denote the water sampling sites, squares with fire the sites for the hot-springs, and crosses the sites for the BDP 1998 and 1999 drilling]

Under field conditions, aseptic techniques were used as far as possible for routine sampling (Gerhardt, 1981). All samples were double bagged and transported at $4{ }^{\circ} \mathrm{C}$ or at $-20^{\circ} \mathrm{C}$ to the laboratories in Koltsovo and Berkeley for further investigation.

- Water samples from depths $0,1,10,45$, and $90 \mathrm{~m}$ were collected in October 1998 at $51^{\circ} 46^{\prime} 30^{\prime \prime} \mathrm{N}, 104^{\circ} 35^{\prime} 00^{\prime \prime} \mathrm{E}$, near Port of Baikal (water temperature decreased with depth from $5.8^{\circ} \mathrm{C}$ to $4.6^{\circ} \mathrm{C}$ ). Further collection was carried out from depths 0,1 , and $10 \mathrm{~m}$ at $53^{\circ} 70^{\prime} \mathrm{N}, 108^{\circ} 53^{\prime} \mathrm{E}$, halfway 
between Snake Island and the St. Nose peninsula (water temperatures 6.0-5. $\left.8^{\circ} \mathrm{C}\right)$.

- In October 1998 three thermal springs near Lake Baikal were sampled, including Snake 1 and 2 (Snake Bay, Barguzin National Park) and hot spring \#116 at Goriachensk. Snake 1 samples included water and sediment. The temperature of the main spring was $45.8^{\circ} \mathrm{C}$; $\mathrm{pH} 7.6$; salt concentration $477.4 \mathrm{mg} / \mathrm{l}$. At Snake 2, water, sediment, and a side spring were sampled. The temperature was $53.8^{\circ} \mathrm{C} ; \mathrm{pH} 9.15$; salt concentration $653.4 \mathrm{mg} / \mathrm{l}$. At Goriachensk, a wooden building covered the hot spring. Water and sediment samples were taken at the spring head, slimy biofilm on the inside of the wooden door, water and sediment at a leak on the south-side of the building, water and soil at the outflow, and biofilm on the wooden wall at the outflow site. The water temperature of hot spring \#116 was $70^{\circ} \mathrm{C}$.

- Sediment samples were obtained from BDP-1998 drilling at the underwater site Akademichesky Ridge $\left(51^{\circ} 45^{\prime} \mathrm{N}, 104^{\circ} 40^{\prime} \mathrm{E}\right)$. At the collection area, the Lake is 1,360-1,400 m deep. A total sub-bottom depth of $320 \mathrm{~m}$ was drilled with each consecutive core being $2 \mathrm{~m}$ in length. Under aseptic laboratory conditions, the $20-\mathrm{cm}$ tip of each 2-m core was removed and the center portion of the sample retained for microbiological work. Between January and October 1998, these samples were kept refrigerated at $4^{\circ} \mathrm{C}$.

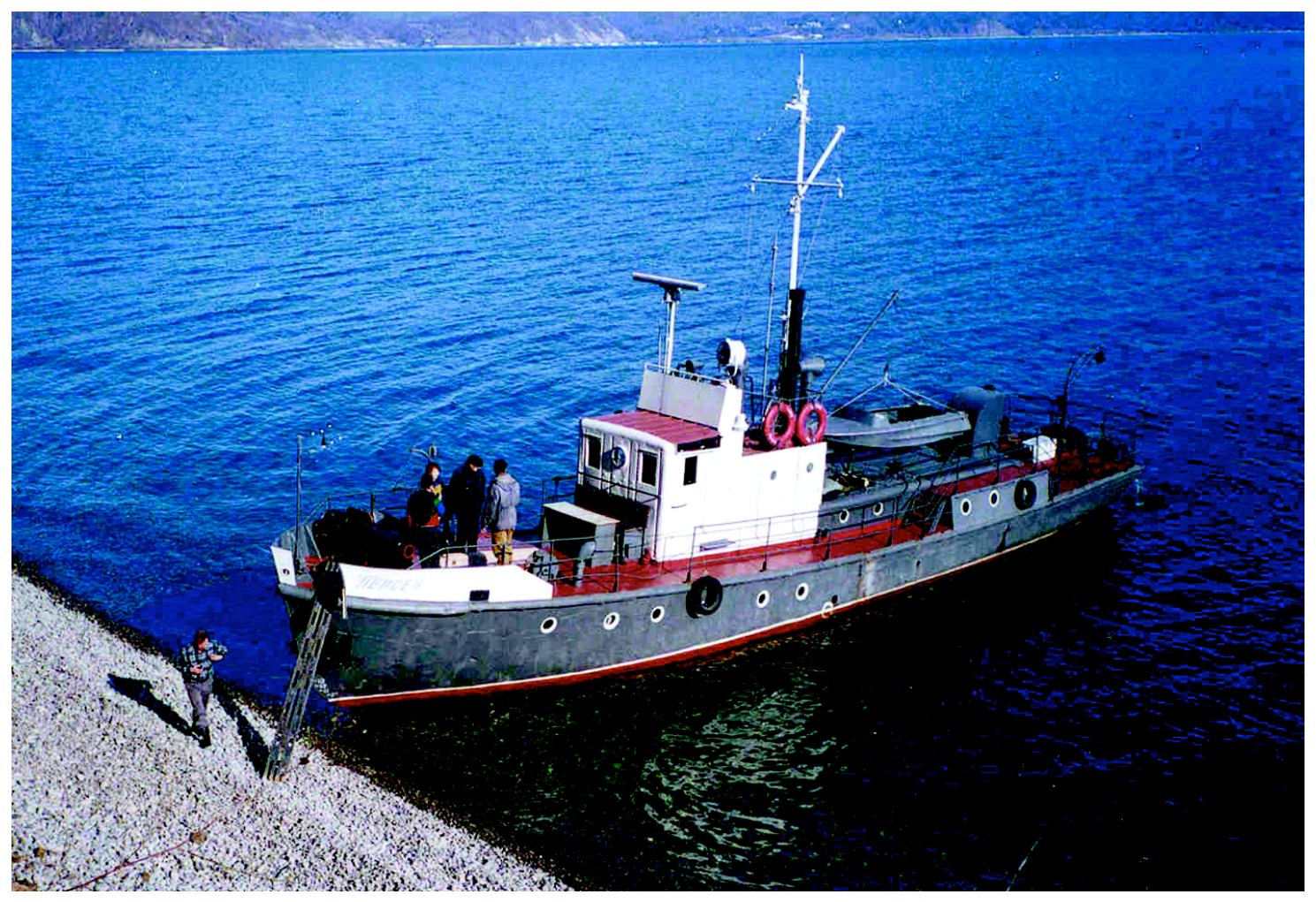

Figure 3 Research vessel used for sample collection in October 1998 
- Sediment samples were collected aseptically during the 1999 BDP drilling (February-March 1999) at the underwater site of Ambassador Bank $\left(52^{\circ} 05^{\prime} 27.1^{\prime \prime} \mathrm{N}, 105^{\circ} 50^{\prime} 23.5^{\prime \prime} \mathrm{E}\right)$. Due to ice drifting, after $130-\mathrm{cm}$ subbottom drilling, a new drilling hole had to be started. During the drilling major earthquakes struck the region and the sediment dropped $70 \mathrm{~cm}$. Depending on geology, hydraulic pressure or piston coring technologies were applied. To monitor drilling mud contamination (Lake Baikal water mixed with $10 \%$ bentonite) of the samples, $1.0-\mu \mathrm{m}$ size surfactant-free fluorescent yellow-green CML polystyrene latex microspheres (Interfacial Dynamics Corp., Portland, OR) were used as described earlier (Colwell et al., 1992; Fredrickson et al., 1993; Phelps et al., 1989). Dating, geological characterization and chemical analysis of the cores is still ongoing.

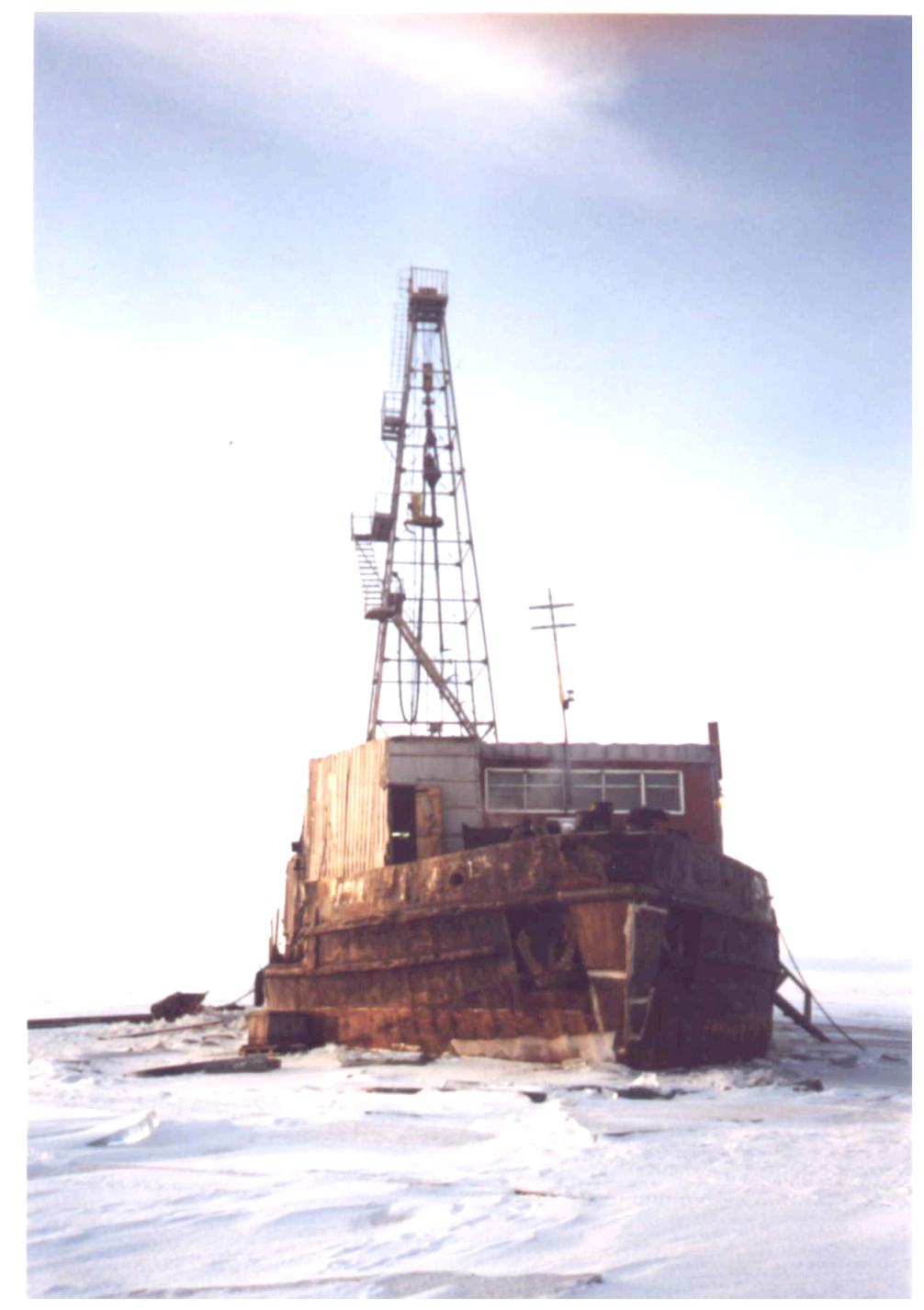

Figure 4 The drilling barge of the Baikal Drilling Project in February 1999 


\subsection{Microbiological Examination}

The investigations focused on isolating bacilli, actinomycetes, and fungi. VECTOR scientists directly plated the water samples. Sub-bottom sediment or soil samples were either suspended and sonicated or dried prior to plating. To increase the number of cultured species, a new separation technique was employed: viable microorganisms were separated from dead cells and sample matrix particles under high-frequency electromagnetic field conditions (Russian patent disclosure filed). All isolation plates were incubated at three different temperatures $\left(4,30\right.$, and $\left.60^{\circ} \mathrm{C}\right)$. The isolated strains were purified, microscopically examined, and preserved for long-term maintenance either at $-86^{\circ} \mathrm{C}$ or by lyophilization. The isolates were identified preliminarily to genus level using standard biochemical tests and cell morphology. A larger subset of isolated strains was imaged by transmission electron microscopy, some also by scanning electron microscopy.

At Berkeley Lab, bulk water samples were directly plated on a set of 9 media (Hunter-Cevera and Belt, 1998). All media were supplemented either with antibacterial or antifungal antibiotics. Colloidal water agar cultures were incubated at $4^{\circ} \mathrm{C}$ for several months. Membrane filters were kept at room temperature in the dark. Subsets of soil and sub-bottom sediment samples were dried in sterile petridishes for 10 days in a biosafety cabinet at room temperature, and then stamped onto the same set of 9 media (Hunter-Cevera and Belt, 1998). The drying process reduced the viable number of other microorganisms and thus, supported the isolation of endospore-forming bacilli, actinomycetes, and fungi. Inoculated cultures were incubated at three temperatures (4, room temperature and $60^{\circ} \mathrm{C}$ ). Isolation was carried out after a few days, several weeks, and several months of incubation. The isolated strains were purified, microscopically examined, and preserved using glycerol as a cryoprotective agent for long-term maintenance at $-86^{\circ} \mathrm{C}$.

Subsets of pre-selected bacteria were exchanged between VECTOR and LBNL. A total of some 200 strains isolated in Berkeley were sent to Koltsovo for restriction enzyme profiling, while some 300 strains isolated in Koltsovo were shipped to Berkeley for further examination.

In Lake Baikal water and the BDP-1998 samples $10^{5} \mathrm{CFU} / \mathrm{ml}$ and $10^{5}-10^{7} \mathrm{CFU} / \mathrm{g}$ of viable microorganisms were detected, respectively. Two orders of magnitude less viable microorganisms were found in the BDP-1999 sediments. Several thermophilic strains were obtained from the hot spring samples. The pure cultures of some 2,200 isolated microorganisms were preserved and are maintained in the culture collections at VECTOR and LBNL. It is understood that some isolates may be duplicates. Dereplication of the strains is ongoing. 


\subsection{Microbial Diversity Characterization}

Isolated and identified strains were subjected to whole-cell fatty acid methyl ester (FAME) analysis, genomic fingerprinting, and restriction enzyme profiling. The latter was chosen because restriction enzymes as members of bacterial restriction and methylation (R-M) enzyme systems monitor the modification patterns of foreign DNA molecules and determine their fate. Earlier, the Russian colleagues had shown that environmental bacterial isolates were an extraordinarily rich source of different R-M systems (Degtyarev et al., 1989; Repin and Shelkunov, 1990; Repin et al., 1988; 1989; 1991; 1992; 1993a; 1993b; 1995a; 1995b). Also, restriction enzymes are useful tools for the analysis of gene structure and function, for cloning and rearrangement of DNA, and as a model of DNA-protein interactions thus, they have a high biodiversity value.

FAME analysis followed manufacturer's recommendations (MIDI, Newark, DE).

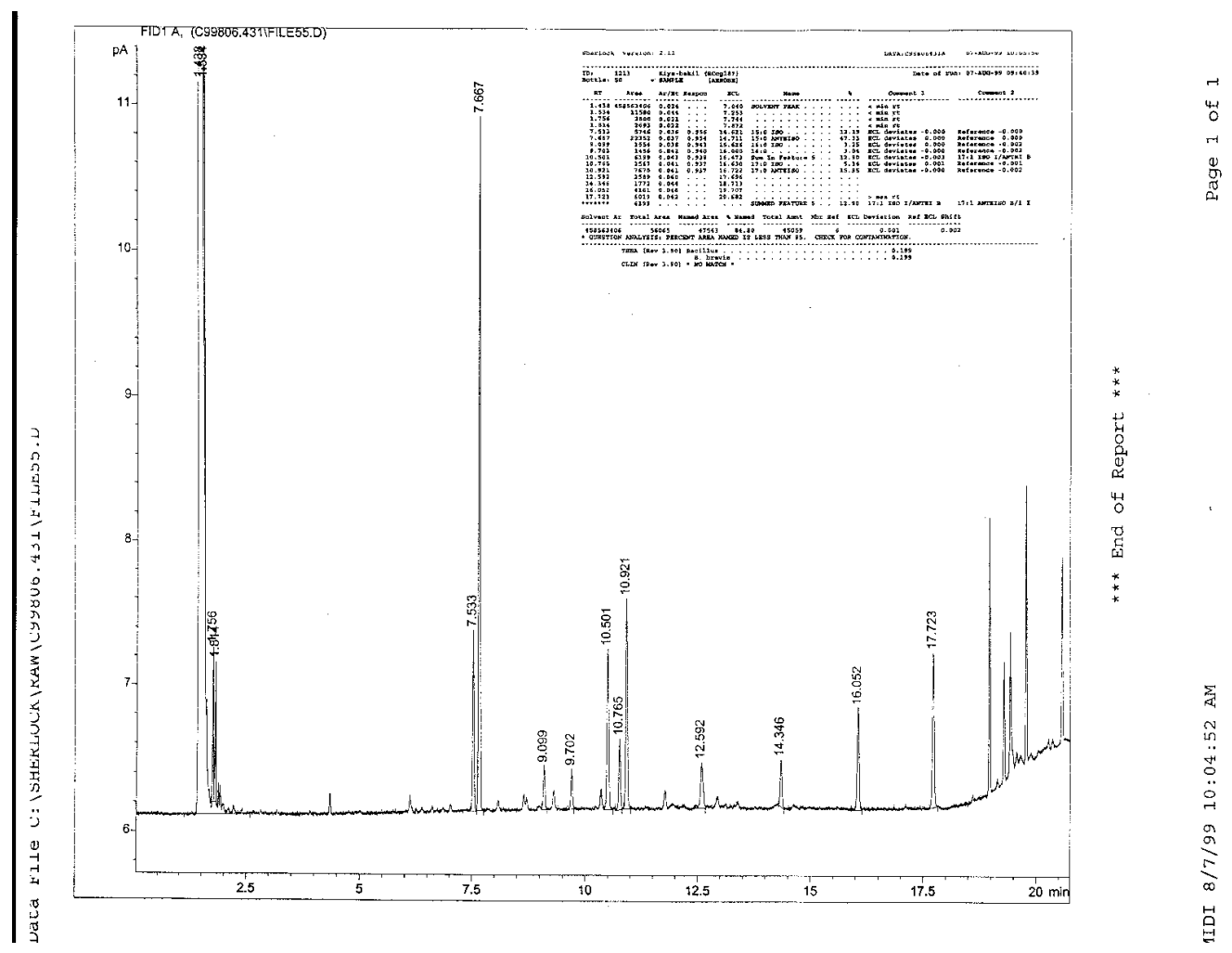

Figure 5 Example of a FAME chromatogram with microbial identification information

Some $80 \%$ of the isolated microorganisms have been analyzed so far. Among the bacteria, 17 genera were represented (Acinetobacter, Arthrobacter, Bacillus, Chryseobacterium, Clavibacter, Curtobacterium, Methylobacterium, Micrococcus, Nocardia, Paenibacillus, Pseudomonas, Rhodococcus, Salmonella, Sphingobacterium, Sphingomonas, Staphylococcus, and Stenotrophomonas). Overall, bacilli (19\%), pseudomonads (11\%) and actinomycetes $(10 \%)$ were the 


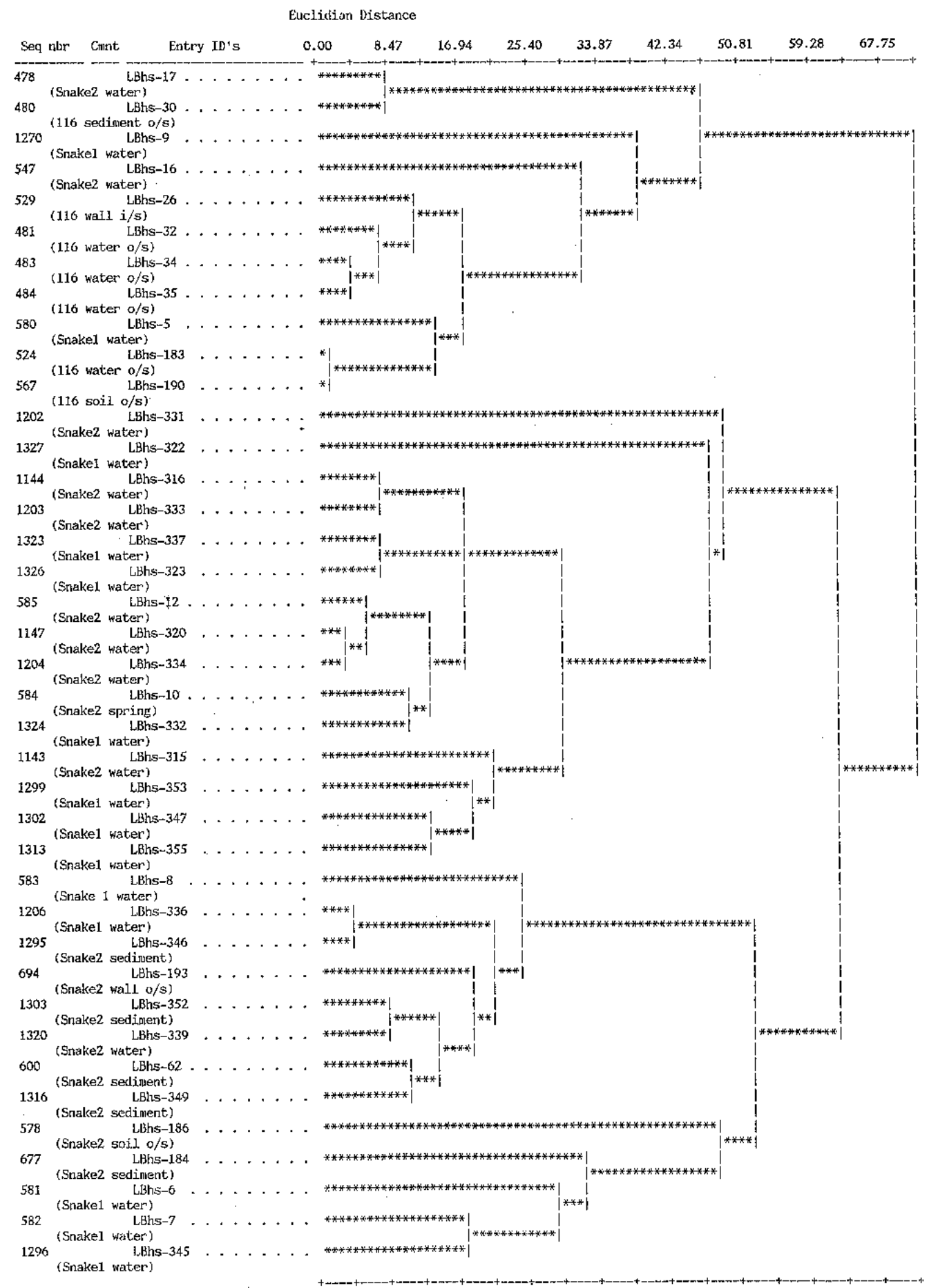

Figure 6 FAME analysis dendrogram of the microorganisms isolated from hot spring samples in 1998. It shows an arbitrary Euclidian distance of relatedness [Note: there are three main branches fungi, Gram- and Gram+ bacteria group separately] 
most abundant bacterial groups. The fungi all belonged to ascomycetous genera, except for two basidiomycetous yeasts. Half of the bacterial isolates and some $70 \%$ of the fungi could not be taxonomically matched to existing database entries. FAME data based microbial diversity was highly dependent on the samples' eco-physiological conditions and the strain pre-selection.

Standard techniques were used for genomic DNA extraction, DNA hydrolysis by endonuclease restriction enzymes, electrophoretic separation of DNA fragments in agarose gels, and for their transfer to nylon membranes [Maniatis, et al, 1982]. After transfer to the membrane, DNA fragments were hybridized with a biotinylated universal probe prepared from single-stranded phage M13mp10 DNA. Following hybridization, the biotin groups were detected as described earlier [Oreshkova et al., 1996; 1999].

A Triton X-100 modification of the rapid method by Repin and Degtyarev [1992] was used to prepare restriction enzymes containing extracts from bacteria. The samples were assayed by incubating the cell extract with DNA from the phages lambda and T7, and the plasmid pBR322. The reaction products were analyzed by electrophoresis in agarose gels. Enzymes were purified by column chromatography. To determine the substrate specificity of the isolated enzymes, viral and plasmid DNA with known nucleotide sequence was used as substrates.

A computer program developed earlier by the Russian colleagues for the identification of restriction endonuclease recognition sites by calculating the lengths of the hydrolysis products was used. The new restriction endonucleases were named in accordance with the relevant nomenclature [Nathans and Smith, 1975].

The cleavage sites for the new recognition sequences were determined by sequencing the fragments of pMVPRL [Bondar et al., 1993] by the modified Maxam-Gilbert method [Prikhod'ko et al., 1988]. SibEnzyme (Russia) produced all commercial restriction enzymes employed in this work.

Via their restriction fragments "finger printing" patterns, we detected genomic polymorphism of closely related strains of microorganisms. Double digestion of genomic DNA with EcoRI + Hindlll gave the most informative set of bands. In determining the specificity of the expressed restriction endonucleases in a subset of some 1,148 strains, we identified widespread activities. We isolated the prototypes of restriction endonucleases, novel enzymes, and some highly productive strains. Among the thermotolerant strains, the new enzyme BssIMI was isolated from a Bacillus stearothermophilus strain. The points of cleavage within the recognition sequence were determined as

$$
\begin{aligned}
& 5^{\prime}-G G^{*} \text { G T C-3' } \\
& \text { 3'-C C C A G*-5' }
\end{aligned}
$$


The new non-palindrome recognizing enzyme may be widely used in genetic engineering because the cohesive ends are compatible with half of the ends produced by the restriction enzymes Avall, PpuMI, and Rsrll. Another restriction enzyme, BstSWI, recognized a 5'-ATTTAAAT-3' cutting site. It is the first thermostabile enzyme, cutting this site with major genome analysis importance.

\subsection{Discussion and Conclusions}

Microbiological investigation of Lake Baikal bottom sediments begun in the late 1920s. In recent years studies have diversified and dealt with microorganisms isolated from Lake Baikal water, bottom sediments, and hot springs, and with the fate of organic matter in microbial mats. After all, our expeditions provided the first non-coastal samples. We investigated the microbial diversity present and its potential for bioprospecting.

The use of fluorescent polystyrene latex microspheres during the sub-bottom coring and sample retrieval proved to be simple. It provided an excellent monitoring tool for contamination exclusion. The applied sample treatments and the intensive isolation program were successful. Our isolation approach was based on distinct colony and cell morphology rather then on isolating every growing microbial colony in every sample. A large number of microbial strains were isolated and preserved. Their screening for important enzymes, secondary metabolites, and other novel capabilities will continue after the closing of this project.

Substantial numbers of viable colony forming units (CFUs) were detected in the water samples and the hot springs. The microbiota appeared to be quite diverse. The hot spring samples provided a number of thermotolerant strains, of which some displayed novel or rare capabilities. Compared to the BDP-1998 samples, there were significantly lower numbers of microorganisms present in the BDP1999 sediments. Since no dominant species was identified in the BDP-1998 samples, contamination during sampling or cold storage could be excluded. The main difference between the BDP-1998 and BDP-1999 samples was due to the microbial and geological heterogeneity of the different sampling sites.

No thermophilic microorganisms were isolated from Lake Baikal water and sediment samples. Neither were statistically different viable numbers found for psychrotrophic and mesophilic microorganisms. Therefore, it is assumed that most microorganisms isolated from sub-bottom sediments and from Lake Baikal water were tolerant to cold temperatures, such as the average water temperature of $3-6^{\circ} \mathrm{C}$.

The fatty acid methyl ester analysis as a preliminary characterization tool proved to be very helpful. The method is simple, eloquent, and highly reproducible. The resulting chromatograms are strain-specific and allow extensive database building and comparison. 
Preliminary core sample dating information estimated the age of the deepest sediments sampled to be more than 10 million years. While the structure of the intrinsic microbial community in the samples was most certainly influenced by pore water infiltration from the water column above the sediments, our finding of rarely occurring combinations of restriction enzymes, such as $\mathrm{Bg} / \mathrm{l}$ and $\mathrm{Bg} / \mathrm{ll}$, appeared to point to the recovery of "ancient" microorganisms.

Understanding microbial diversity is imperative. For it is the role microorganisms play in conservation and restoration biology of higher organisms, and it is the tool in monitoring and predicting changes in the environment. How microbial communities develop and function is the model for understanding biological interactions, evolutionary history, and sustainability of life on our planet. Discovering the untapped diversity of microorganisms is the resource for new genes and products of value to biotechnology. A relatively pristine and in geological terms "ancient" ecological niche, such as Lake Baikal may prove very valuable. In the future, it will take the joint effort of microbial physiologists and molecular biologists to resolve the impasse between the challenge of exploring the enormous wealth of microbial diversity and the availability of currently limited tools and prior knowledge.
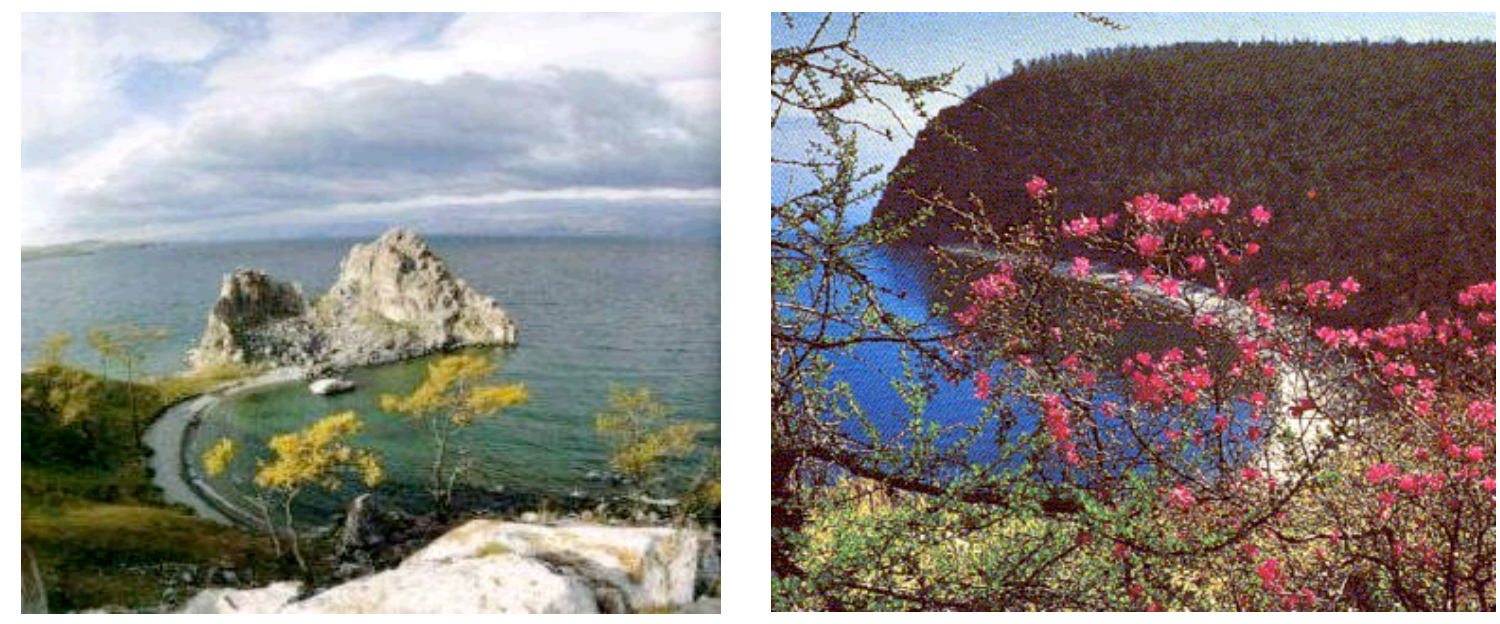

Figure 7 Lake Baikal, Russia, October 1998 


\section{Publications and Presentations}

Andreeva I., Ryabchikova, E., Pechurkina, N., Zajtsev, B., Geletij, V., Korobushkina, E., Vinogradova, T., Torok, T., Hunter-Cevera, J. C., and Repin, V. 2001. Morphological analysis of aerobic microorganisms in deep drilling core samples. Geology and Geophysics (Russia) [in press].

Preuss, P. 1998. Siberian journey: on the trail of ancient microorganisms. Berkeley Lab Currents, November 20, 1998

Preuss, P. 1998. Siberian journey: on the trail of ancient microorganisms. http://www.lbl.gov/Science-Articles/Archive/ancient-microorganisms.html

Preuss, P. 1999. Life beneath the surface. Research Review. http://www.lbl.gov/Science-Articles/ResearchReview/Magazine/1999/stories/story3b.shtml\#top

Preuss, P. 1999. Siberian journey. http://www.lbl.gov/ScienceArticles/Research-Review/Magazine/1999/departments/health.shtml

Repin V., Geletij, V., Bakirov, T., Generalov, V., Andreeva, I., Puchkova, L., Repina, M., Torok, T., Hunter-Cevera, J. C. 1999. The bottom of Lake Baikal: an unexplored territory of microbial diversity. $18^{\text {th }}$ Annual General Meeting of the European Culture Collections' Organization (ECCO), Sestri Levante, Italy, Abstracts p. 1

Repin, V., Torok, T., Kuzmin, M. I., and Hunter-Cevera, J. C. 1999. Unusual restriction enzyme profiles of Bacillus spp. isolated form Lake Baikal water and sediment samples. $4^{\text {th }}$ International Symposium on Subsurface Microbiology, Vail, CO., Abstracts p. 77.

Repin, V., Torok, T., Andreeva, I., Oreshkova, S., Vinogradova, T., Bakirov, T., Generalov, A., Toporkov, V., Repina, M., Geletij, V., Hunter-Cevera, J. C. 1999. Microbiological investigation of deep subsurface sediment samples in the framework of the Baikal Drilling Project. $4^{\text {th }}$ USA/CIS Joint Conference on Ecology, Environment, and Human Health, San Francisco, CA., Abstracts p. 21.

Repin, V., Torok, T., and Kuzmin, M. I. 2001. Biodiversity of deep sub-bottom sediments of Lake Baikal. Geology and Geophysics (Russia) [in press].

Repin, V., Torok, T., Degtyarev, S., Abdurashitov, M., Puchkova, L., Andreeva, I., Pechurkina, N., Hunter-Cevera, J. C., Geletij, V., and Kuzmin, M. I. 2001. Microbiological and biotechnological investigations of sub-bottom sediments of Lake Baikal and samples of closely located hot springs (Zmeiniy, Goryachenskij). Geology and Geophysics (Russia) [in press].

Torok, T., Repin , V., Geletij, V., and Hunter-Cevera, J. C. 1999. Microbial diversity in Lake Baikal water and sediment samples as determined by an extensive isolation program. $4^{\text {th }}$ International Symposium on Subsurface Microbiology, Vail, CO., Abstracts p.77.

Torok, T., Repin , V., Geletij, V., and Hunter-Cevera, J. C. 1999. Microbial diversity in Lake Baikal water and sediment samples as determined by an extensive isolation program. $4^{\text {th }}$ USA/CIS Joint Conference on Ecology, Environment, and Human Health, San Francisco, CA., Abstracts p. 21. 
Torok, T., Hunter-Cevera, J. C., Repin, V., and Geletij, V. 1999. Preliminary assessment of microbial diversity in Lake Baikal water and sediment samples. "Sponsored Biological Research in Russia for the New Millennium" NATO Workshop, Novosibirsk, Russia, pp. 46-63.

Torok, T. and Repin, V. 1999. Bioprospecting in Siberia at Lake Baikal. Centerfor Environmental Biotechnology Seminar, Berkeley, CA.

Torok, T. 2000. Microbial diversity and the Rio Convention. Bioprospecting at Lake Baikal. Molecular and Cellular Biology Department Seminar, Berkeley, CA.

Torok, T. 2000. Bioprospecting in Siberia. Radiation Biology Group Seminar, Berkeley, CA.

Torok, T. 2000. What we do and why. DOE Teachers' Summer Program Seminar, Berkeley, CA.

Torok, T., Repin, V., Degtyarev, S., and Hunter-Cevera, J. C. 2000. Microbial diversity of Lake Baikal. $19^{\text {th }}$ Annual General Meeting of the European Culture Collections' Organization (ECCO), Paris, Abstracts, pp. 2-3.

Torok, T., Repin, V., Degtyarev, S., and Hunter-Cevera, J. C. 2000. Preliminary characterization of the microbial diversity in water, sub-bottom sediment, and hot-spring samples at Lake Baikal in Russia. $100^{\text {th }}$ General Meeting of the American Society for Microbiology, Los Angeles, CA., Abstracts pp. 387-388.

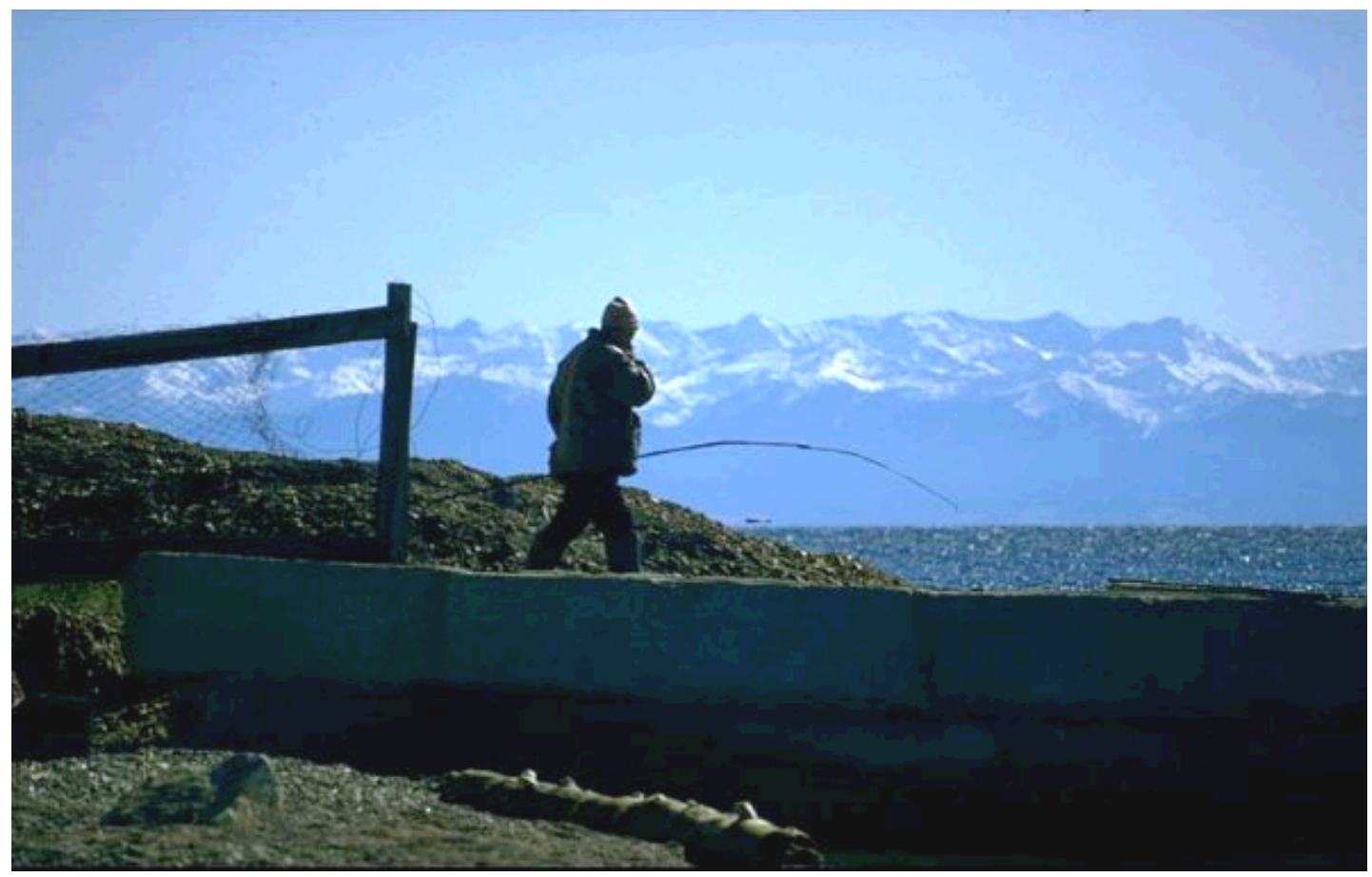

Figure 8 Lake Baikal, Russia, October 1998 


\section{Acknowledgement}

This project was supported by a DOE grant (GJ0902000 TF; LBNL-T1-0018) and a subcontract (6480540) under the IPP program.

The principal investigators want to express their deepest appreciation for all the support they received from colleagues at the Institute for Geochemistry of the Russian Academy of Sciences, Irkutsk and the Buryat Institute of Geology in Ulan Ude. Director M.I. Kuzmin and microbiologist T. A. Vinogradova in Irkutsk, and geophysicist and deputy director G. I. Tatkov in Ulan Ude were instrumental in making the sampling expeditions a success. Special thanks are due to the Baikal Drilling Project and the members of the Russian drilling crew lead by V. Romashov and S. Kotchukov for their professional understanding and support during those freezing weeks of sample collection.

In Dr. Repin's laboratory, I. S. Andreeva, L. I. Puchkova, and N. I. Pechurkina carried out most of the isolation work. Special thanks to V. Toporkov, T. Bakirov, and V. Generalov for the separation of viable microorganisms with the highfrequency electromagnetic field instrument.

T. Torok wishes to recognize Kiyanna Merchant and Berenice Villatoro for their dedication and eagerness in working in a highly professional manner. Special thanks are due to G. Dahlbacka, LBNL's ILAB representative. Without his active support this project could have not achieved its goals. T.T. also wants to thank G. Peter (National Collection of Agricultural and Industrial Microorganisms, Hungary) for his help in identifying the yeast strains.

\section{References}

Bondar, A.A., Golovin, S.J., and Mertvetsov, N.P. 1993. Sib.Biol.J (Russia) 2:10-15

Colwell, F. S., Stormberg, G. J., Phelps, T. J., Birnbaum, S. A., McKinley, J., Rawson, S. A., Veverka, C., Goodwin, S., Long, P.E., Russell, B. F., Garland, T., Thompson, D., Skinner, P., and Grover, S. 1992. Innovative techniques for collection of saturated and unsaturated subsurface basalts and sediments for microbiological characterization. J. Microbiol. Meth., 15:279-292.

Degtyarev, S. K., Zilkin, P. A., Prichodko, G. G., Repin, V. E., and Rechkunova, N. I. 1989. Determination of unusual substrate specificity of the restriction endonuclease Bpu10 I. Molec. Biol. (USSR), 23:1051-1056.

Fredrickson, J. K., Brockman, F. J., Bjornstad, B. N., Long, P. E., Li, S. W., McKinley, J. P., Wright, J. V., Conca, J. L., Kieft, T. L., and Balkwill, D. L. 1993. Microbiological characteristics of pristine and contaminated deep vadose sediments from an arid region. Geomicrobiol. J., 11:95-107.

Gerhardt, P. (Editor-in-chief) 1981. Manual of methods for general bacteriology. American Society for Microbiology, Washington, D. C.

Hunter-Cevera, J. C. 1998. The value of microbial diversity. Curr. Opinion Microbiol., 1:278-285. 
Hunter-Cevera, J. C. and Belt, A. 1998. Isolation of cultures. In: Davies, J. E. and Demain, A. L. (Eds.) Manual of industrial microbiology and biotechnology, $2^{\text {nd }}$ edition, pp. 3-20, ASM Publication, Washington, D.C.

Maniatis, T., Fritsch, E. F., and Sambrook, J. 1982. Molecular cloning : a laboratory manual. Cold Spring Harbor, N.Y., Cold Spring Harbor Laboratory.

Nathans, D. and Smith, H. O. 1975. Restriction endonucleases in the analysis and restructuring of DNA molecules. Annu. Rev. Biochem., 44:273-293.

Oreshkova, S.F., Manokhina, O.V., Puchkova, L.I., Repin V.E., and Il'ichev A.A. 1996. Identification and characterization of microorganism strains by the genomic fingerprinting technique with biotinylated phage M13 DNA. Genetika (Russia) 32:740-743.

Oreshkova, S.F., Burtseva, L.I., Puchkova, L.I., Repin V.E., and Il'ichev A.A. 1999. Identification and characterization of Bacillus thuringiensis strains by the genomic fingerprinting technique with biotinylated phage M13 DNA. Genetika (Russia) 35:751-755.

Phelps, T. J., Fliermans, C. B., Garland, T. R., Pfiffner, S. M., and White, D. C. 1989. Methods for recovery of deep terrestrial subsurface sediments for microbiological studies. J. Microbiol. Meth., 9:267-279.

Prikhod'ko, G.G., Petrov, N.A., Chizhikov, V.E., and Degtyarev, S. K. 1988. Biotekhnologiya (Russia) 4:618-620.

Repin, V. E. and Degtyarev, S. K. 1992. Comparison of express-methods used for the detection of restriction endonucleases in microorganisms. Priklad. Bioh. Microbiol. (USSR), 28:152-155.

Repin, V. E. and Shelkunov, S. N. 1990. Occurrence and function of restriction endonucleases (a review). Usp. Sovr. Biol., 110:34-47.

Repin, V. E, Babkin, I. V., and Tereshchko, T. A. 1993a. Bse118 I, an isischizomer of the Cfr10l restriction endonuclease from Bacillus coagulans. Bioorg. Khim. (Russia), 19:406-409

Repin, V. E., Prichodko, E. A., and Degtyarev, S. K. 1988. Search of soil microorganisms for production of restriction endonucleases. Izv. Sib. Otd. Akad. Nauk SSSR Ser. Biol. Nauk (USSR) 14:110-113.

Repin, V. E., Burtseva, L. I., Burlak, V. A., and Trusova, S. I. 1991. Search for restriction endonuclease producers with required specificity. Molec. Genetic, Microbiol. Virus.(USSR), 11:20-22.

Repin, V. E, Chizhikov, V. E., Tereshchko, T. A., and Lebedev, L. R. 1993b. Bco116 I, an isischizomer of Ksp632 I from Bacillus coagulans. Bioorg. Khim. (Russia), 19:410-413.

Repin, V. E, Puchkova, L. I., Rodicheva, E. K., and Vydrjakova G.A. 1995b. Luminescent bacteria as producers of specific restriction endonucleases. Microbiol. (Russia), 64:751-755.

Repin, V. E., Rechkunova, N. I., Degtyarev, S. K., Hachaturyan, A .A., and Afrikyan, E. K. 1989. Aerobic spore-forming bacteria producers of restriction endonucleases. Biol.J. Armenia, 42:969-972.

Repin, V. E., Serov, G. D., Babkin, I. V., Puchkova, L. I., and Chizhikov, V. E. 1992. Determination of the substrate specificity of restriction endonuclease Bsh45 I. Sibirsk. Biolog. J. (Russia), 6:14-15. 
Repin, V. E, Lebedev, L. R., Puchkova, L., Serov, G. D., Tereshchenko, T., Chigikov, V. E., and Andreeva, I. 1995a. New restriction endonucleases from soil thermophilic bacteria. Gene, 157:321-322.

Williams, D. F. and BDP-93 Baikal Drilling Project Members. 1997a. Preliminary results of the first scientific drilling on Lake Baikal, Buguldeika site, southeastern Siberia. Quart.Intern., 37:3-17.

Williams, D. F. and Baikal Drilling Project Members. 1997b. Continuous paleoclimatic record recovered for last 5 million years. EOS, December 23, pp.597, 601, 604.

Williams, D. F., Peck, J., Karabanov, E. B., Prokopenko, A. A., Kravchinsky, V., King, J., and Kuzmin, M. I. 1997c. Lake Baikal record of continental climate response to orbital insolation during the past 5 million years. Science, 278:1114-1117.

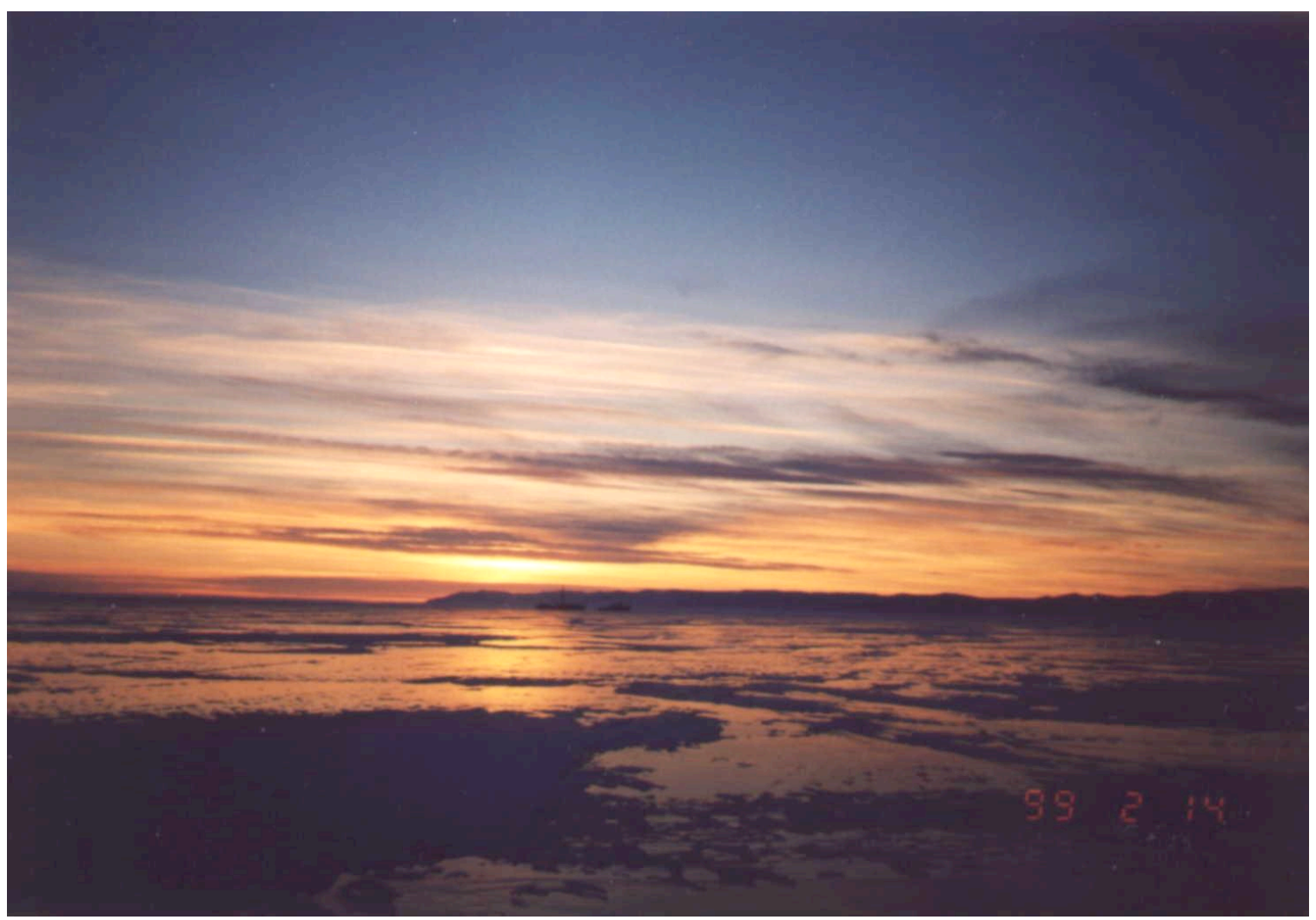

Figure 9 Sunset over Lake Baikal in February 1999 